Zaeem Hassan Mehmood, Ramla Khan | Assessing the Indian Ocean Economics: Perspective from Pakistan

Article

\title{
Assessing the Indian Ocean Economics: Perspective from Pakistan
}

\author{
Zaeem Hassan Mehmood ${ }^{1}$, Ramla Khan ${ }^{2}$ \\ ${ }^{I}$ PhD Scholar International Relations \& Political Science, Greenwich University, Karachi, Pakistan \\ ${ }^{2}$ MPhil Scholar International Relations, National Defence University, Islamabad, Pakistan
}

\section{SUBMISSION TRACK}

\author{
Received : 10 September 2020 \\ Final Revision : 06 December 2020 \\ Available Online : 01 May 2021
}

\section{KEYWORD}

Indian Ocean, Geoconomics of the Indian Ocean, Indian Ocean and Pakistan, Multilateral

Maritime Matrix, Maritime Heartland, Complex

Interdependence, Maritime Diplomacy, Blue

Economy

\section{KATA KUNCI}

Samudra Hindia, Geoekonomi Samudra Hindia, Samudra Hindia dan Pakistan, Matriks Maritim Multilateral, Interdependensi Kompleks,

Diplomasi Maritim, Ekonomi Biru

\section{CORRESPONDENCE}

$\begin{array}{ll}\text { Phone } & :+92332-3005726 \\ \text { E-mail } & : \underline{\text { zhmehmood24@gmail.com }} \\ & \underline{\text { ramla.khan2418@gmail.com }}\end{array}$

A B S T R A C T

The Indian Ocean offers "global commons" the sea lanes of communication that connects the East with the West. These nurture the global economic world by providing a classical instance of 'multilateral maritime matrix,' whereby merchant ships manufactured in one country, are maintained and owned by another, underwritten by third, registered in fourth and crewed by subjects of another. The concerns of nation-states thereby extend from its immediate maritime borders to the protection of chokepoints. For Pakistan, the progress on China-Pakistan Economic Corridor, a flagship project of Belt and Road Initiative has added to the country's geo-economic connotation. The government realizing the immense maritime economics potential has declared 2020 as the 'Year of Blue Economy'. The paper uses qualitative mode of study to scrutinize primary and secondary data sources available at maritime/port authorities, think-tanks and other affiliates in Pakistan. The conceptual setting of 'Complex Interdependence' supplements the scholarly insight by considering trade ties as vital deterrent to antagonistic rivalry among the regional and extra-regional states. The paper concludes that sea is vital for trade, security and the environment. In the post-Covid times, it would be play a crucial role in revamping economic growth.

\section{A B S T R A K}

Samudra Hindia menawarkan "kekayaan alam global" berupa jalur komunikasi laut yang menghubungkan Timur dengan Barat. Kondisi ini memelihara dunia ekonomi global dengan memberikan contoh klasik 'matriks maritim multilateral,' di mana kapal dagang yang diproduksi di satu negara, dipelihara dan dimiliki oleh negara lain, ditanggung oleh pihak ketiga, terdaftar di pihak keempat dan diawaki oleh subjek negara lain. Kekhawatiran negarabangsa dimulai dari perbatasan maritim hingga ke perlindungan choke points. Bagi Pakistan, kemajuan Koridor Ekonomi China-Pakistan, sebuah proyek unggulan Inisiatif Sabuk dan Jalan telah menambah konotasi geoekonomi negara itu. Pemerintah yang menyadari potensi ekonomi maritim yang sangat besar telah mencanangkan tahun 2020 sebagai 'Tahun Ekonomi Biru'. Artikel ini menggunakan model studi kualitatif untuk meneliti sumber data primer dan sekunder yang tersedia di otoritas maritim/pelabuhan, think-tank dan afiliasi lainnya di Pakistan. Pengaturan konseptual 'Interdependensi Kompleks' melengkapi pandangan ilmiah dengan mempertimbangkan hubungan perdagangan sebagai pencegah vital terhadap persaingan antagonis di antara negara-negara regional dan ekstra-regional. Artikel ini menyimpulkan bahwa laut sangat penting untuk perdagangan, keamanan, dan lingkungan. Di masa pascaCovid, kondisi ini akan memainkan peran penting dalam pembenahan pertumbuhan ekonomi. 
Zaeem Hassan Mehmood, Ramla Khan | Assessing the Indian Ocean Economics: Perspective from Pakistan

\section{Introduction}

The Indian Ocean (IO) facilities the "global commons" by providing the sea lanes of communication (SLOCs) that connects the East with the West. The SLOCs provides a classical instance of 'multilateral maritime matrix,' whereby merchant ships are manufactured in one country, maintained and owned by another, underwritten by third, registered in fourth and crewed by subjects of another. ${ }^{1}$ In this regard, the strategic and commercial concerns of nation-states extends from its immediate maritime borders to the protection of those chokepoints at the high-seas where merchandise is most vulnerable to an array of contemporary security threats. The notion of "complex interdependence," propounded by Joseph Nye and Robert Keohane, is significant in understanding the maritime dynamics of the IO from an international relations and security perspective.

The third largest ocean, since the cessation of bipolar hostilities with the demise of Cold War, has been integrated with the global markets to a critical extent whereby any interruptions to the established trade networks is likely to have a "shockwave effect". The IO is presaged to continue as a "central shipment pathway" for regional and inter-continental trade in wide range of commercial commodity items. ${ }^{2}$ The patterns observed in the region consists of up gradation of existing port facilities and developing export markets and resources based on principles of blue economy which is likely to strengthen maritime collaboration. These trends have the potential to permit the

\footnotetext{
${ }^{1}$ Antoine Fremont, "Global Maritime Networks. The Case of Maersk. Journal of Transport Geography," Elsevier, 2007, Vol. 15, no. 6: 431-442.

${ }^{2}$ Robert Kaplan, "Center Stage for the Twenty-First Century: Power Plays in the Indian Ocean." Foreign Affairs (2010): 16-32.
}

IO to be the "strategic heart of the maritime world". 3

The global center shift towards the east in the IO has had direct bearing on the economic activities of the region. The vital SLOCs have seen tremendous expansion in trade flows of vital energy commodities. The rising India and China having one of the highest economic growth rates rely heavily on the safety and stability of Indian Ocean Region (IOR). The latter is projected to take over the US as the leading economy by 2025 whereas India is also likely to continue the upward trajectory. ${ }^{4}$ Pundits mostly agree on this growth scenario, other experts show dubiety. In their vistas, the economic development of Beijing and New Delhi could be stalled by abundant structural domestic hitches concerning to sociopolitical stability, the established political rules, and demographic challenges. They might detain the dawn of an 'Asia-Pacific Era, ${ }^{5}$ if economic and population factor in these countries does continue persistently, it will have a reflexive effect for their industrial demand for fossil by-products. The two Asian powers hinge heavily on fossil fuels, which are anticipated to rise to $75 \%$ and $95 \%$ in regard to their cumulative oil requirements by 2030 . As a repercussion, the two countries will rely extensively on imported energy imports by sea, particularly from the Gulf, thus boosting the stature of the IO as a transit passageway. ${ }^{6}$

The bulk of traffic passes through the vital choke points at the corresponding

\footnotetext{
${ }^{3}$ Robert Kaplan, Monsoon the Indian Ocean and the Future of American Power (New York: Random House, 2011), 13-14.

4 T.V Paul, "When Balance of Power Meets Globalization: China, India and the Small States of South Asia," Politics, 39(1) (2010): 50-63.

5 J. Gilson, "A European Pivot Towards Asia? Interregionalism in a New Era," In The European Union in the Asia-Pacific (Manchester: MUP, 2019).

${ }^{6}$ C. Len, "China's 21st Century Maritime Silk Road Initiative, Energy Security and SLOC Access," Maritime Affairs: Journal of the National Maritime Foundation, 11(1) (2015): 1-18.
} 
Zaeem Hassan Mehmood, Ramla Khan | Assessing the Indian Ocean Economics: Perspective from Pakistan

points of the ocean. In the West is the Babel-Mandeb and Strait of Hormuz whereas in the East is located the Strait of Malacca, responsible for carrying more than 200 vessels each day and one third of globe's trading goods. ${ }^{7}$ A number of nations have started organizing maritime patrols around the strategic passages to protect their valuable merchandise from violent non-state actors, is an indicative that in the long-run energy security can bring the major powers to a standoff in the region. ${ }^{8}$ Conversely, rivalry over scarce energy assets in the IO locale might be alleviated by the mutual interests to proceed with stability and financial developments of the region.

China and India, in the recent times despite the increasing economic interdependence have shown a degree of wariness towards each other which has resulted in border skirmishes and diplomatic incident. Commentators are of the opinion that for the two states, economic interdependency functions as a deterrent to antagonistic rivalry. ${ }^{9}$ The figures for 2019 shows that accumulated trade has increased to USD 92.5 billion and is projected to be on an upward trajectory, whereas in the 1990 it was USD 262 million. $^{10}$ It can be therefore said that strong geo-economic ties can pacify existing rivalries. The same as an element of foreign policy and diplomatic relations can be extended towards improving the liaison of region and extra-regional stakeholders from confrontational behavior towards cooperation in the IO. ${ }^{11}$

7 L. Kang, Q, Meng and Liu Q, "Fundamental Diagram of Ship Traffic in the Singapore Strait," Ocean Engineering, 147 (2018): 340-354.

8 R, Kaplan, "Center Stage for the Twenty-First Century: Power Plays in the Indian Ocean," Foreign Affairs (2019): 16-32.

9 Robert Jervis, "Cooperation under the Security Dilemma," World politics, 30(2), (1978):167-214.

10 Trade Map Statistics, "Trade Statistics for International Business Development," (2018) URL: https://www. trademap.org

11 R. Kaplan, Monsoon the Indian Ocean and the Future of American Power (New York: Random House, 2011).

\section{Research Method}

In the years succeeding the China Pakistan Economic Corridor (CPEC), national studies on the subject-matter have increased manifold however they have been focused more on the IOR rather than the IO itself due to the traditional land-based orientation of the individuals. In order to address these research gaps, the paper uses qualitative mode of analysis to study existing literature relating to the IO. The primary sources of data include policy documents and strategy papers of leading states relating to the region which have been scrutinized on the basis of discourse analysis. Courtesy of National Institute of Maritime Affairs (NIMA), a national think-tank formulated by government of Pakistan, the author was privileged to visit the coastal areas of Pakistan from Karachi to Jiwani, where informal discussions were held with public and private stakeholders. These insights were valuable for the completion of this article. Added to that, author as an Associate Editor for Maritime Watch (MW), Pakistan's first news digest on maritime affairs interviewed the Minister for Maritime Affairs and other key figures in Ports and Shipping for MW, which remain vital to thought process and understanding of the country's maritime economy. A disclaimer maybe added that following study is based on the opinion of the authors and in no way is the representation of any national or public institution mentioned in the article.

In a transitioning regional and international setting, theoretical frameworks by a set of assumptions (ceteris paribus) provide scholarly guidance on the futuristic trends and patterns. Complex Interdependence, in this regard underlies why due to economic and political reasons extra-regional states have an active involvement in the IO. It also considers that due to high stakes of bilateral trade amounting to several billions of dollars, states such China and India, despite their on- 
Zaeem Hassan Mehmood, Ramla Khan | Assessing the Indian Ocean Economics: Perspective from Pakistan

going differences at the border would rationally deescalate their hostilities.

\section{Complex Interdependence: Conceptual Setting}

Geo-economics has gradually become an important most tool in the foreign policy conduct whereby states are rallying on their economic ties and might to further their strategic interests. Robert D. Blackwell and Jennifer Harris in War by Other Means: Geo-economics and Statecraft have defined it as the use of the economic influence to defend national interest by producing viable geopolitical conclusions. Since Joseph Nye and Robert Keohane in Power and Interdependence laid the foundations of "complex interdependence," pundits and intellectuals from diverse political aspirations have debated whether economic interdependence works. This revered debate in strategic studies assesses whether it leads to pacification or aggravation of conflict among nations. ${ }^{12}$ The proponents of the former school derive their fundamentals from liberal theory arguing that global commerce has conciliated the politics of nations. The latter nevertheless argue that dependence makes the states vulnerable to leverage and friction, causing rising tensions. While a large literature has developed concurring the importance of interdependence in endorsing mutual peace and prosperity, studies also exist that are somewhat neutral or inadequately conform to the viewpoint offered by liberal academician. 13

The contributions of "complex interdependence" in elucidating the global security transitions after the demise of Cold War have been vital and well-recognized by

12 James Cable, "Interdependence: A Drug of Addiction?" In Diplomacy at Sea (London: Palgrave Macmillan, 1985), 55-73.

13 E. Mansfield and B. Pollins, "The Study of Interdependence and Conflict: Recent Advances, Open Questions, and Directions for Future Research," Journal of Conflict Resolution 45, no. 6 (2001: 834-59. international scholars. Similarly, at the state level, policymakers re-envisioned their foreign and national strategies to cater for the importance and functioning of supra-national institutions. For Keohane and Nye, interdependence has altered the realities and conduct of international relations, by bringing in economics, human security and ecological concerns roughly at par with traditional concerns involving war and strategy.

Furthermore, there are the "non-state" or "non-territorial" stakeholders comprising of multinational conglomerates and international organizations that are playing a prominent role in a number of sectors. Considering the IO and the maritime economics, there are a number of organizations that are involved. The Indian Ocean Rim Association (IORA), is an intergovernmental organization deals with facilitating its members in trade, scientific cooperation, aqua-culture and non-traditional security aspects. The Indian Ocean Tuna Commission (IOTC) has the responsibility for the regulation of tuna fish in the IO. The International Maritime Organization (IMO), is an UN specialized agency that is responsible for safety and security of shipping. The state, therefore, is required to cooperate and work with a number of "nonstate" institutions for not only the maritime/regional stability but also for achieving its national security objectives.

Complex Interdependence believes that for policymakers of the state, there are a numerous issues to deal with, however since the intricacy involved in them, it is rather difficult to prioritize them hierarchy wise. For Nye and Keohane, military matters would play reasonably less importance in such scenarios. ${ }^{14}$ Military actions have become rather costly due to a number of developments including nuclear weapons and the dissuading effects of Mutually

\footnotetext{
14 Robert Keohane and Joseph Nye, Power and Interdependence (New York: Little, Brown and Company, 1977).
} 
Assured Destruction (MAD). Moreover, a full-fledged war can have adverse effects on the economy. In an age of globalization, where citizens and civil society are more active than ever before, a war can damage the social legitimacy of the regime in power. Finally, there is the dilemma for statesmen and all policymakers regarding the uncertainty of military means whether they would be able to bring in desired results or maybe other means such as severing trade ties and other pressure tools of diplomacy would be more effective. ${ }^{15}$

Keohane and Nye, have indicated that as a result of increasing communications between the states the likelihood of conflicts have been reduced by manifolds. It is argued that in prior times, policymakers were relatively more ambiguous about the intentions of other states, which has to an extent been resolved via opening of new channels of communications between the people and society along with government officials. The media in this regard, considered as the fourth pillar of state by investigating particular incidents and occurrences have helped promote mutual understanding between states. ${ }^{16}$ In the long term, these initiatives can be extended to allow for security understanding or organization of some sort, for instance in the IO by the regional states exclusively dealing with threats emancipating from the sea. ${ }^{17}$ For better comprehension, Keohane and Nye debate between the conceptions of interdependence as distinct from dependence, whereas the former is instrumental in deterring and limiting conflict by "creating an alternative venue where states can compete that does not require military violence," the latter upturns the prospects for

15 Iskander Rehman, "Drowning Stability: The Perils of Naval Nuclearization and Brinkmanship in the Indian Ocean," Naval War College Review, 65(4) (2012): 64-88.

16 Philip Seib, Future of Diplomacy (Bristol: Polity Press, 2016)

17 C. Glaser, "The Security Dilemma Revisited," World Politics, 50(1) (1997): 171-201. non-dependent nations to intimidate the state that is reliant on it.

The IO has been called by Kaplan as the region that would define the fate of US, he is of the opinion that in the future the region is likely to see a multi-polar power competition whereby the regional states such as China, India, Indonesia, Australia, Japan and Pakistan are likely to play an important role as balancers. The Belt and Road Initiative (BRI) of China has been dubbed by experts as an "economic power tool to project influence in the Asia-Pacific and combat the geopolitics of militarily superior US." ${ }^{18}$ It is an interesting scenario, depicting a change of luck and stride, whereby states that were in previous centuries colonized and subjugated as a result of European imperialism are major players not only in the IO but also in the globe, as reflected by the growing membership of Asia-Pacific states in G20, and they have to their disposal finances and resources to invest in state-ofthe art maritime capabilities.

\section{Discussion and Analysis}

The IOR is indispensable asset to the livelihoods and security of its littoral states. The IO is, despite the challenges anticipated to become a dominant global geopolitical and economic force. ${ }^{19}$ The immense significance highlighted by various experts make this datum irrefutable that IOR will be acting as one of the significant regions in geostrategic and geo-economics terms in the $21^{\text {st }}$ century. With approximately half the global population is anticipated to reside in the IOR countries by $2050 .{ }^{20}$ This clearly is signifying that how vital this rim is to

18 Pervaiz Cheema, "Indian Ambitions in the Indian Ocean and the Pacific Rim: The Response of Global and Regional Powers," Journal of European Studies 28, no. 2 (2012).

${ }^{19}$ R. D. Kaplan, Monsoon the Indian Ocean and the Future of American Power (New York: Random House, 2011).

20 David Brewster, India as an Asia Pacific Power (London: Routledge, 2012). 
transform in very recent times to come. Currently the universe is embowered with 7.7 billion population out of which 2 billion already reside in the IOR. ${ }^{21}$ The geopolitical shift is altering its identity from the 'Ocean of the South' to the 'Ocean of the Centre', and further to the 'Strategic Heart of the Maritime World' as its core position in terms of global trade, industry, human resource, environment and security is likely to shape the $21^{\text {st }}$ century world. ${ }^{22}$

The contribution of IOR to global economy has increased manifold it was a mere average of seven percent in 1980 (1.4 billion USD) to 10 percent ( 80 trillion USD) by 2017 . The national income of only three IOR countries National Income of only three IOR countries-i.e., Australia, Singapore and Qatar is categorized under the table of the leading twenty states with highest gross national income per capita. ${ }^{23}$ Added to that, trade pacts between IO states have seen a considerable rise in the passage of last few years. ${ }^{24}$ It is substantial in regard to the commercial and security connotations whereby almost half of global trade navigates via its passageways. The region holds an assortment of natural land and seabased resources, which can add to the region's economy. ${ }^{25}$

Despite the impressive statistics, it can be said that IO is not living up to its potential, at least economically. It is way behind in

21 C. Bouchard, and W. Crumplin, "Neglected No Longer: The Indian Ocean At The Forefront Of World Geopolitics and Global Geostrategy," Journal of the Indian Ocean Region, 6(1) (2010): 26-51.

22 T. Doyle and G. Seal, "Indian Ocean Futures: New Partnerships, New Alliances And Academic Diplomacy," Journal of the Indian Ocean Region, 11(1) (2015): 2-7.

${ }^{23} \mathrm{H}$. Singh, "Geo-Strategic Environment in the Indian Ocean: Contemporary Trends," Asian Journal of Multidimensional Research (AJMR) 7, no. 10 (2018): 229-246.

${ }^{24}$ Sergei Silva, "Fact Sheet: The Indian Ocean Region and Australia's National Interests," Strategic Analysis Paper, Future Directions Australia 29 (2012).

25 Rear Adm. M. McDevitt, Becoming a Great Maritime Power: A Chinese Dream (Arlington: CNA, 2016), 148-160. comparison with the rest of the regions when it comes to market liberalization and trade pacts. ${ }^{26}$ This is also a result of the regional power structure, as a number of IO states are still developing countries with having limited resources and capacity. Although, a number of regional organization such as Indian Ocean Rim Association (IORA) exist in the region, they are in relatively nascent stages or interstate rivalry or exclusion of some regional participants have limited their effectiveness. A number of countries have taken initiative in this regard, which has the potential to provide necessary stimulus to IO economy. Primary of which includes China's BRI, an ambitious mega-project designed to revive the ancient silk route. Despite the strategic delusion and concern of the US, BRI under the principles of "complex interdependence" is likely to pacify existing regional hostilities and provide a framework for cooperative growth in the IO. ${ }^{27}$ However, as the dictums of international relations and past historical experiences suggest, it would be wise for states to upgrade and invest in their own capabilities rather than relying on outside solutions, which always has the risk of giving strategic concessions to the other states.

\section{Challenges to Economic Development of IOR}

The states in the IO share a common history and chronicles ties brought together by the ocean. A major challenge since the decolonization process has been regional cooperation. This has been made difficult due to a number of internal and external challenges. These also include the inability of the regional states to resonate with the differences in regards to the population and

\footnotetext{
26 Lyndon E. Llewellyn, Susan English and Sharon Barnwell, "A Roadmap to a Sustainable Indian Ocean Blue Economy," Journal of the Indian Ocean Region, 12:1 (2016): 52-66.

${ }^{27}$ W. Liu and M. Dunford, "Inclusive Globalization: Unpacking China's Belt and Road Initiative," Area Development and Policy, 1(3) (2016): 323-340.
} 
cultural traditions. In some cases, these have been fueled by the age-old "divide and rule" dictum of imperial powers, in other cases they have been used by political elites.

The collective problems involving all relatively prosperous and weak IO states include urbanizing of major town, industrialization and migration that has from a maritime perspective resulted in exploitation of marine resources over and beyond the limit advised by the ecological experts. ${ }^{28}$ It is expected that regional states to have an exponential population growth by 2050; which could make the region home to approximately half of global populace. Although a number of achievements as a result of trade liberalization and agreements have taken place. It is contended by Chellaney that IO at a regional level is "far from being a 58 community of common values". ${ }^{29}$ This is because the governance mechanisms have a number of gaps that has delayed the execution of blue growth.

At the strategic level, it is anticipated that Africa is to rise both geo-economically and on the geopolitical scale. For IO, this could have mixed effects, it could mean states in Africa having more cognizance of maritime realm whereas it can also result in increasing challenges further by bringing in more actors, making cooperation due diverse point of view, national interests and priorities difficult. In other regions such as South Asia and East Asia, fortunes are expected to improve further. The present trends comprise of persistent economic growth, considerable part of which is likely to be used to modernize military capabilities. In recent times, due to tensions at the Strait of Hormuz, the subject-matter of energy security is also high on the agenda on states such as China, India, Japan and South Korea which together

\footnotetext{
${ }^{28}$ M. Gupta, Indian Ocean Region: Maritime Regimes for Regional Cooperation (Heidelberg: Springer, 2014).

29 Brahma Chellaney. "Indian Ocean Maritime Security: Energy, Environmental and Climate Challenges," Journal of the Indian Ocean Region 6, no. 2 (2010): 155-168.
}

consume up to 40 percent of the strategic chokepoints accumulated transit of oil and gas.

The regions are also impacted by the international developments, in particular the strategic posture of US. The presidency of Donald J. Trump has revisited American approach towards the IO under the "IndoPacific strategy," a shift from former president Barack Obama's "Asia-Pacific vision" (also known as "Pivot towards Asia"). The approach of present administration can also be signified from the National Security Strategy (NSS) 2017, which has termed the IO as immensely significant to the US interests. Adding that, at the global level, a multi-polar power competition is emerging fuelled by "revisionist" states such as Russia and China. The way forward suggested in the policy doctrine is to relentlessly pursue American interests, empower and military equip regional allies such as India and Australia, to roll-back the interests of the adversaries. ${ }^{30}$ These challenges of strategic and defensive nature at the regional and international level may hinder economic growth. Policymakers may be required to place their resources to address the "gun v butter debate".

\section{COVID-19 Pandemic and the Blue}

\section{Economy}

The COVID-19 pandemic is unprecedented in our lifetimes, impacting all economies depending on the evolution cycle of the disease and on the types of prevention and remedial measures takes. The Blue economy sectors contributions to global GDP are around 4 to 7 percent, which have been heavily impacted. ${ }^{31}$ The epidemic has limited global fishing efforts and also hampered production of other maritime

\footnotetext{
30 National Security Strategy of United States of America (Washington D.C: Office of the US President, 2017).

31 UNCTAD. "2020 Investment Trends Monitor: Special Issue," March 2020.
} 
goods and services, affecting dependent value chains globally. Disruption of supply side capacity, including transport routes, limited access to ports, falling demands have undermined the sector. Coastal and maritime tourism, the largest of all blue economy sectors served as an essential source of income and investment for many countries including those in the IOR. UNWTO has revised its international tourist arrivals target from to $4 \%$ growth to a deep decline of almost 20 to 30 per cent. ${ }^{32}$ Cruise tourism has been particularly affected, with some companies having to put entire crew and passengers under quarantine. More than 50 million jobs are at a risk in the cruise affiliated tourism, although recovery measures according to health experts would depend on the length of restrictions. ${ }^{33}$ It is however, likely that as restrictions are lifted many people running tired of confinement may run to coastal areas in a quest to contact with nature, open air and water, leading to sudden increase in demand.

\section{Triangular Relationship: India, China and Pakistan}

The strategic landscape of the region will be defined by the complex interactions between three powers - China, India and Pakistan. The US withdrawal from Afghanistan, is likely to wane the former's influence in the short term, the complex relationship between the three powers, with the physical absence of the US, is likely to define parameters of a new regional order. Recently, the first fatal border clash since 1975 and most serious since 1967 occurred between the Chinese and Indian troops along the Himalayan border running along Ladakh

\footnotetext{
${ }^{32}$ UNWTO, "COVID-19: UNWTO Calls on Tourism to be Part of Recovery Plans," https://www.unwto.org/news/covid-19-unwtocalls-on-tourism-to-be-part-of-recovery-plans.

${ }^{33}$ S. Baker, N. Bloom, S. Davis and S. Terry, "COVID-induced Economic Uncertainity," Working Paper 26983, (April 2020) National Bureau of Economic Research, Massachusetts.
}

area of Kashmir. ${ }^{34}$ A view that, hostilities on India-China border would keep India engaged with China and thus easing pressure on Pakistan has been proven a misgiving. Pakistan's strategic community has voiced concern that unable to respond militarily to Chinese physical occupation of disputed strategic altitudes of Aksai Chin and Lakakh, it is likely that India turn its frustration and aggression towards Pakistan for face-saving. This has practically been demonstrated by stepping up gunfire on the Line of Control (LoC) and violations of air space. The strategy can serve well for the Indians, to pressurize and weaken Pakistan's growing economy. It can also serve as good ploy for diverting the attention of millions of Indians from their economic challenges and possibly serve as a cover against humiliating Indian military performance against China.

For India, challenging China is a longterm project. Presently, economic and military of China far outshine that of the former. In this regard, India enjoys political, economic and strategic clout of the US. In this situation, Pakistan may be required to lean more on China to counter India's aggressive designs. For China, it would be strategically convenient to strengthen its ties with Pakistan. A wave of anti-China sentiments have swept in India, demanding for boycotting of Chinese manufactured goods and suspension of all technology and industrial cooperation. It is however, doubtful that these threats would ever materialize considering that bilateral trade between the states crosses over $\$ 95.5$ billion that neither government rationally would like to give up. ${ }^{35}$ Robert Keohane and Joseph

34 Saif Khalid, "India China Border Tensions: A New Flashpoint in South Asia," Al-Jazeera, June 18, 2020,

https:/www.aljazeera.com/news/2020/06/india -china-border-tension-flashpoint-south-asia200617152644516.html

35 Talat Masood, "Implications of the India-China Conflict," Express Tribune, June 24, 2020, https://tribune.com.pk/story/2249024/6implications-india-china-conflict/. 
Nye elaborating their concept of "Complex interdependence" strongly believe that interdependence can pacify conflicts as waging a war would be irrational for the states considering the trade sum at stake. Furthermore, during these times of economic downturns, when COVID-19 has hit hard on global economy, it would be unwise for either party to wage war. ${ }^{36}$

\section{Strategic Impacts of the IOR}

The safety of strategic waterways and uninterrupted maritime traffic is a key priority for trading states from and beyond the IO. At the turn of the present century, non-traditional security threats in the form of piracy near Somalia and similar maritime criminals proximate to the Strait of Malacca gave rise to question of maritime security cooperation among the regional stakeholders. $^{37}$

The Gulf, on the other side, although being currently prone to the highest risk of an unyielding military conflict, for the West the Gulf states and Iran represent much of the world's petroleum exports performing a cardinal role in the global economy. ${ }^{38}$ The roll-back of dialogues amid the P5+1 have intensified the nuclear facet, though this may take several years to fully prove and determine. It has not paused the Tehran's alleged lengthy build-up of major ballistic missile forces, regional vying for influence between Iran and Arabs states and the risk of asymmetric war in the Gulf, a major

36 "The Global Economic Outlook During the COVID-19 Pandemic: A Changed World," World Bank, June 8, 2020, https:/www.worldbank.org/en/news/feature/2020/06/ 08/the-global-economic-outlook-during-the-covid-19pandemic-a-changed-world

37 B. Schreer, "Towards Contested 'Spheres of Influence' in the Western Pacific: Rising China, Classical Geopolitics, and Asia-Pacific Stability," Geopolitics, 24(2) (2019): 503-522.

${ }^{38}$ Faisal Bin Salman, Iran, Saudi Arabia and the Gulf: Power Politics in Transition (London: IB Tauris, 2003). conventional arms race. The broader brawl for influence over Iraq, Syria, and Lebanon; and the growing strains and conflicts in Yemen are less containable. The Gulf Subregion poses the most serious near-term strategic risk to the geo-economics in the IOR. $^{39}$

In the epicenter of the IOR, exist the nuclear armed neighbors Pakistan and India, the latter have a fuller strategic and economic weightage, the antique rivalry and unsettled Indo-Pak crisis over Kashmir and water issue keep the chances of another war alive. ${ }^{40}$ The both ends being nuclear armed entities have relatively prepared a high level of mutual deterrence. The confrontations on borders continue particularly from Indian side. The nuclear weapon arsenals are updated along with the non-traditional threat of terrorism, piracy in maritime traffic fringing the IOR border lands. In the Western Indian Ocean, Somalia has traditionally been the trouble spot for piracy whereas in the Eastern Indian Ocean concerns have been shown around the Strait of Malacca. US has built partnership with a variety of regional states safeguard Gulf oil exports and the security of maritime traffic throughout the region. ${ }^{41}$ The US is committed to a strategy that gives the Middle East and Asia highest-priority. ${ }^{42}$ Asia has already swapped the West as the chief energy importer and source of maritime commerce within the IOR, and China has steadily surged its dimensions of exports and import dependence over time. Thus under these continuing acrimonies in the IOR

\footnotetext{
39 Nazery Khalid, "The Role of Indian Ocean in Facilitating Global Maritime Trade," In The Security of Sea Lanes of Communication in the Indian Ocean Region (London: Routledge, 2016), 109-119.

40 Christophe Jaffrelot, The Pakistan Paradox: Instability and Resilience (Oxford University Press, 2015).

41 Admiral James Stavridis, Sea Power: The History and Geopolitics of the World's Oceans (New York, Penguin Books, 2018).

42 R. Kaplan, Monsoon: The Indian Ocean and the Future of American Power (New York: Random House, 2011).
} 
between it will be interesting to note how China and the US compete and converge for influence in the "ocean of the center".

\section{Way Forward}

The Covid-19 epidemic has overwhelmed healthcare systems and paralyzed economies across the world. There is apprehension regarding its impact in developing part of the world. IOR has been vulnerable because of high population density and limited government resources. ${ }^{43}$ World Bank reports that the region comprises of low and middle-income countries who have rising levels of external debt and their economies are highly dependent on external sources of income such as textile and tourism. ${ }^{44}$ Furthermore, the loss of remittances from overseas employees in the Gulf has also condensed their national economies. The countries of IOR have in the modern times increasingly been seen as a contest of influence between regional and global powers. China has provided assistance to the region in form of testing kit deliveries, personal protective equipment and other medical supplies.

From a geoeconomic standpoint, IOR has been a major focus of BRI and in the immediate future COVID-19 has severely impeded its progress. It is foreseen that in the events of a global financial downturn, the requirement for developing new infrastructure would considerably be reduced. ${ }^{45}$ Many planned projects in the region may likely be put to an interruption in the immediate future. Beijing realizing the nature of the crisis has already decided to ease the burden on region's developing

\footnotetext{
43 S. Gössling, D. Scott and C. M. Hall, "Pandemics, Tourism and Global Change: A Rapid Assessment of COVID-19," Journal of Sustainable Tourism, (2020): $1-20$.

${ }^{44}$ N. Fernandes, "Economic Effects of Coronavirus Outbreak (COVID-19) on the World Economy," SSRN 3557504 (2020).

45 P. Tonchev, "The Belt and Road After COVID19," The Diplomat, April 7, 2020.
}

countries by providing debt relief, loans and rescheduling existing debts. Nevertheless, notwithstanding significant disruptions in Chinese sponsored developmental intiatives across the world, Pakistan, China's principal strategic partner is pressing ahead with CPEC. ${ }^{46}$

The recent India-China border standoff has caused serious concerns to the international community. The global spectators in particular are observant regarding the role of Pakistan, considering that as a neighborly country it can offer a productive role as a mediator to the standoff. Pakistan in this regard has a history of successful mediation in patching up relations between even the most aggravated powers. ${ }^{47}$

A notable example would be facilitating the opening of formal US-China relations, which resulted in historic visit of the then US President Richard Nixon to China. ${ }^{48}$ Nevertheless, the states in the West are attentive to the fact that strategy makers of India and Pakistan consider each other as archrivals, and hawks would be hesitant to not let go of such opportune moment. However, an assumption that Pakistan would push to escalate tensions would be one based on premeditated conclusion, as neither would want a "Nuclear Armageddon". The founding father of Pakistan, Quaid-e-Azam Muhammad Ali Jinnah (R.A) envisaged the foreign policy of Pakistan to be based on promotion of peace and prosperity among all nations:

"Our foreign policy is one of friendliness and goodwill towards all the nations of the world. We do not cherish

${ }^{46}$ I. Kickbusch, G. M. Leung, Z. Bhutta, A. Matoso, K. Abbasi, "COVID-19: How a Virus is Turning the World Upside Down, BMJ Editorial: 369 (2020) doi: 10.1136/bmj.m1336.

47 "China, India Need No US Mediation in Border Dispute: Beijing, The Nation, May 29, 2020, "https://nation.com.pk/29-May-2020/chinaindia-need-no-us-mediation-in-border-dispute-beijing ${ }^{48}$ Riaz Mohammad Khan, "Pakistan-China Relations: An Overview," Pakistan Horizon 64, no. 3 (2011): 11-28. 
aggressive designs against any country or nation. We believe in the principle of honesty and fair play in national and international dealings and are prepared to make our utmost contribution to the promotion of peace and prosperity among the nations of the world. Pakistan will never be found lacking in extending its material and moral support to the oppressed and suppressed people of the world, and in upholding the principles of the United Nations Charter." 49

Pakistan can additionally utilize the platforms of South Asian Association for Regional Cooperation (SAARC) and Shanghai Cooperation Organization (SCO) to facilitate cooperation between India and China. It may be noted that Pakistan and India are member to the former organization whereas in the latter all three including China are members.

\section{Conclusion and Recommendation}

In the $21^{\text {st }}$ century international political environment overshadowed by globalization and complex interdependence, the gravity center has moved from the land to the sea. However, the understanding and appreciation of the significance of the sea remains limited, termed by naval experts as "sea blindness". ${ }^{50}$ In the IO, a number of nations and regional organizations are started to take maritime security seriously by making it a preference on their policy concerns. ${ }^{51}$

The seas have therefore transformed into realms termed as vital for trade, security and environment. They are a major juncture

49 Quaid-e-Azam (R.A) 1948 Broadcast Message to the American People, http://mofa.gov.pk/foreignpolicy-2/

50 J. Dua, Captured at Sea: Piracy and Protection in the Indian Ocean"

51 C. Bueger and T. Edmunds, "Beyond Seablindedness: A New Agenda for Maritime Security Studies," International Affairs 93:6 (2017). of contemporary international relations, where the interests of states converge in general on maritime stability and security. However, they diverge on the methods, matters and procedure as to how to achieve it. The regional states, a number of them are wary of outside solutions, including extraregional presence. This has also been as a result of history and past experiences which eventually led to outside powers colonizing thriving and prosperous states for a couple of centuries. It is forecasted that the strategic environment in the IO would remain complex and would be characterized by "interdependence, vulnerability and competition. ${ }^{52}$

For Pakistan there are important takeaways in the transitioning geoeconomics from the West to Asia. The IO necessitates a re-examination of priorities by the highest decision makers of Pakistan, considering it is the only coastal opening for the country. There is a need to exploit the geostrategic location that is at the confluence sub-regions of South Asia, West Asia and Central Asia. It is recommended that revamping of the maritime sector would provide for a strong geo-economic posture and must be given top-level priority. A solid shipping sector of a country is a bed rock for viable and prosperous economy. ${ }^{53}$ The regional success stories range from Panama to Liberia and Marshall Island earning several billions of dollars from their shipping registries. China has now emerged as a maritime nation leading shipbuilding across the globe and a closer cooperation in the merchant navy would provide the desire impetus. ${ }^{54}$ It is concluded that the maritime future of the IO would have geo-economic repercussions beyond the region, therefore all the nations including Pakistan need to

\footnotetext{
52 Diane French, David Michel, and Ricky Passarelli, "Sea Change," Stimson Centre, December 2014.

53 V/Adm. Khawar Ali Shah, "Shipping Sectors Potential." Dawn News, May 29, 2019.

54 Hamid Hussain, Indian Maritime Ambition for Domination of IOR (MPhil Thesis, Islamabad: NDU,
} 2015). 
Zaeem Hassan Mehmood, Ramla Khan | Assessing the Indian Ocean Economics: Perspective from Pakistan

gear up in order to maximize the best out of the "strategic heart of the maritime world". In order to contribute its national share, Pakistan under the leadership of Prime Minister Imran Khan has declared "2020 as Year of Blue Economy". The concept is a maritime equivalent of the "green economy" which was first elaborated by Gunter Pauli at a UN Conference on Sustainable Development Goals (SDGs)..$^{55}$

Uncertainty presently dominates the outlook for the blue economy as the extent and duration of the pandemic is yet to be clear. All blue sectors are being negatively impacted by COVID-19 outbreak, particularly in the IOR region which has been heavily impacted by the downturn trends in global demand, falling commodity prices, eroding export earnings, capital outflows and declining tourist revenues and remittances. The maritime sector will be crucial in revamping the global economy and other related financial segments.

55 "Blue Economy Policy to Help Save Foreign Exchange: PM Imran Khan," (2020, August, 16), The News International 
Zaeem Hassan Mehmood, Ramla Khan | Assessing the Indian Ocean Economics:

Perspective from Pakistan

\section{REFERENCES}

Bouchard, C, and Crumplin, W. Neglected No Longer: The Indian Ocean At The Forefront Of World Geopolitics and Global Geostrategy. Journal of the Indian Ocean Region, 6(1) (2010): 26-51.

Bueger and Edmunds, "Beyond Seablindness: A New Agenda for Maritime Security Studies." International Affairs 93:6, 2017.

Cable, J. Interdependence: A Drug of Addiction?. In Diplomacy at Sea. Palgrave Macmillan, London, 1985.

Cheema, P. I. Conflict and Cooperation in the Indian Ocean: Pakistan's Interests and Choices. Canberra: Strategic and Defence Studies Centre, Australian National University, 1981.

Cordner, L. Progressing Maritime Security Cooperation in the Indian Ocean. Naval War College Review, 64(4) (2011): 68-88.

Doyle, T., \& Seal, G. Indian Ocean Futures: New Partnerships, New Alliances and Academic Diplomacy. Journal of the Indian Ocean Region (2015): 2-7.

Fernandes, N. Economic Effects of Coronavirus Outbreak (COVID-19) on the World Economy. SSRN 3557504 (2020).

Gilson, J. A European Pivot Towards Asia?: Inter-regionalism In a New Era. In The European Union in the Asia-Pacific. Manchester University Press, 2019.

Gupta, M. Indian Ocean Region: Maritime Regimes for Regional Cooperation. Heidelberg: Springer, 2014.

Holmes, James R. and Toshi Yoshihara, Chinese Naval Strategy in the 21st Century: The Turn to Mahan, Routledge, London and New York, 2008.

Jaffrelot, C. The Pakistan Paradox: Instability and Resilience. Oxford University Press, 2015.

Jervis, R. Cooperation Under the Security Dilemma. World Politics. 30(2) (1978):167-214.

Kennedy, P. M. Grand Strategies in War and Peace. New Haven: Yale University Press, 1992.

Kennedy, P.M. The Rise and Fall of Great Powers: Economic Change and Military Conflict from 1500 to 2000. Harper Collins, 1989.

Khan, I., Farooq, S., \& Gul, S. China-Pakistan Economic Corridor: News Discourse Analysis of Indian Print Media. Journal of Political Studies, 23(1) (2016).

Khan, R. Resource Amassement as A Tool of Maximizing Sea Power in the Indian Ocean. Andalas Journal of International Studies (AJIS), 8(1) (2019): 62-74.

Len, C. China's 21st Century Maritime Silk Road Initiative, Energy Security and SLOC Access. Maritime Affairs: Journal of the National Maritime Foundation of India, 11(1) (2015): 1-18.

Liu, W., \& Dunford, M. Inclusive Globalization: Unpacking China's Belt and Road Initiative. Area Development and Policy, 1(3) (2016): 323-340.

Lyndon E. Llewellyn, Susan English \& Sharon Barnwell, "A Roadmap to a Sustainable Indian Ocean Blue Economy," Journal of the Indian Ocean Region, 12:1, 52-66 (2016).

Malik, A. H. History of Pakistan Merchant Navy: 1947-2009. A and C Black, 2010.

Michel David and Russell Sticklor, Indian Ocean Rising: Maritime Security and Policy Challenges, Stimson, Washington D.C., 2012.

Mija, V., \& Teosa, V. (2014). Is the Complex Interdependence the Last Evolution of Globalization. Materialele Conferinţei Ştiinţifice Internaţionale. Political Science, International Relations and Security Studies.” Ediţia VIII, Sibiu, (2014): 165-175.

National Security Strategy of United States of America. Washington D.C, 2017.

Nawaz, R. R. Maritime Strategy in Pakistan. Naval Post Graduate School Monterey CA, 2004. 
Zaeem Hassan Mehmood, Ramla Khan | Assessing the Indian Ocean Economics:

Perspective from Pakistan

Pakistan Navy, Maritime Doctrine of Pakistan. Naval Headquarters. Islamabad, 2018.

Paul, T. V. When Balance of Power Meets Globalization: China, India and the Small States of South Asia. Politics, 39(1) (2019): 50-63.

Rehman, Iskander. "Drowning Stability: The Perils of Naval Nuclearization and Brinkmanship in the Indian Ocean." Naval War College Review 65, no. 4 (Autumn 2012): 64-88. ProQuest document ID: 1036961008.

Reus-Smit, Christian, and Duncan Snidal. The Oxford Handbook of International Relations. Oxford: Oxford University Press, 2010.

Ross, Michael L. Oil Curse - How Petroleum Wealth Shapes the Development of Nations. Princeton University Press, 2013.

Russell, James. "The Indian Ocean." In Maritime Strategy and Global Order: Markets, Resources, Security, edited by Daniel Moran and James Russell Washington, DC: Georgetown University Press, 2016.

Sakhuja, V. Asian Maritime Power in the 21st Century: Strategic Transactions: China, India, and Southeast Asia. Shahpur Jat, New Dehli: Pentagon Press, 2012.

Schreer, B. Towards Contested 'Spheres of Influence' in the Western Pacific: Rising China, Classical Geopolitics, and Asia-Pacific Stability. Geopolitics, 24(2) (2019): 503-522.

Seib, P. Future of Diplomacy. Polity Press, 2010.

Sempa, F.P. Geopolitics: From the Cold War to the 21st Century. Transaction Publishers, 2007.

Shah, Khawar Ali V/Adm. Shipping Sectors Potential. Dawn News. May 29, 2019. https://www.dawn.com/news/1484729/shipping-sectors-potential

Tangredi, S. J. Globalization and Maritime Power. Honolulu, HI: University Press of the Pacific, 2004.

Tonchev, P. The Belt and Road After COVID-19. The Diplomat, April, 72020.

UNCTAD. Investment Trends Monitor March 2020, Special Issue. United Nations Conference on Trade and Development.

Váli, Ferenc. Politics of the Indian Ocean Region: The Balances of Power. New York: The Free Press, a Division of Macmillan Publishing Co., Inc., 1976. 
Zaeem Hassan Mehmood, Ramla Khan | Assessing the Indian Ocean Economics: Perspective from Pakistan

\section{BIOGRAPHY}

Zaeem Hassan Mehmood is $\mathrm{PhD}$ scholar at Department of International Relations \& Political Science, Greenwich University Karachi, Pakistan. He has Masters of Philosophy in Strategic Studies specializing in maritime security arrangements in the Indian Ocean from National Defence University Islamabad, a prestigious institute of Pakistan dedicated to the study and research of military science, geo-strategy and international relations. Mr. Zaeem is an alumni of the $2^{\text {nd }}$ Faculty Development Training Workshop organized by Faculty Development Center, National Defence University (NDU), Islamabad. He has given guest lectures on regional security developments and the importance of maritime security construct for Pakistan at Bahria University and NDU. He has served as Research Associate (Maritime Trade \& Economy) at National Institute of Maritime Affairs, a think tank established by Government of Pakistan at Bahria University to provide policy guidelines to the maritime sector. Until recently, he was also an Associate Editor (International \& Regional News) for Maritime Watch, Pakistan's first maritime news digest published on a monthly basis to promote maritime domain awareness among the masses. He is Manager Research \& Analysis for securities and oil market.

Ramla Khan is Masters of Philosophy scholar at Department of International Relations, National Defence University Islamabad, Pakistan. She has extensively written on matters of global strategy, security and disinformation operations with a special focus towards development in the Asia-Pacific region. Her writings have appeared on reputed national and international platforms, including the Austral: Brazilian Journal of Strategy and International Relations, Malaysian Journal of International Relations (MJIR), Andalas Journal of International Studies (AJIS) and Straf Asia United Kingdom. Ms. Khan has also served as Public Relations Officer at Strategic Vision Institute, a multi-disciplinary and nonpartisan think-tank based in Islamabad. She is reviewer for International Journal of Interdisciplinary Global Studies, Common Grounds Research Network University of Chicago, United States. 